\title{
A successful case of biological invasion: the fish Cichla piquiti, an Amazonian species introduced into the Pantanal, Brazil
}

\author{
Resende, EK.*, Marques, DKS.* and Ferreira, LKSG. \\ Empresa Brasileira de Pesquisa Agropecuária - EMBRAPA Pantanal, \\ Rua 21 de Setembro, 1880, CEP 79320-900, Corumbá, MS, Brazil \\ *e-mail: emiko@cpap.embrapa.br, marques@cpap.embrapa.br \\ Received May 23, 2007 - Accepted June 21, 2007 - Distributed November 30, 2008
}

(With 6 Figures)

\begin{abstract}
The "tucunaré", Cichla piquiti, an exotic Amazonian fish has become established along the left bank of the Paraguay River in the Pantanal. It was introduced by escaping from culture ponds in the Upper Piquiri River and spread downstream, along the lateral flooded areas of that river, continuing through the clear waters of the left bank of the Paraguay River and reaching south as far as the Paraguai Mirim and Negrinho rivers. Adult spawners have been found in the region, meaning that it is a self-sustained population. Reproduction occurs in the period of low waters. They were found feeding on fishes of lentic environments belonging to the families Characidae, Cichlidae and Loricariidae. Until the end of 2004, its distribution was restricted to the left bank of the Paraguay River, but in March 2005, some specimens were found on the right bank, raising a question for the future: what will be the distribution area of the tucunaré in the Pantanal? Information about its dispersion is increasing: it is known to be in the Tuiuiú Lake, Pantanal National Park and in the Bolivian Pantanal, all of them on the right bank of the Paraguay River. The hypothesis that the "tucunaré" could not cross turbid waters, such as in the Paraguay River, was refuted by these recent findings. Possibly, the tucunaré's capacity to lay more than one batch of eggs in a reproductive period, as well as its care of eggs and young, lead them to establish themselves successfully in new environments, as has been observed in the Pantanal and other localities.
\end{abstract}

Keywords: invasion, dispersion, reproduction, feeding.

\section{Um caso de sucesso de invasão biológica: o tucunaré Cichla piquiti, um peixe amazônico introduzido no Pantanal, Brasil}

\section{Resumo}

O tucunaré, Cichla piquiti, está estabelecido ao longo da margem esquerda do rio Paraguai, desde a área do seu escape no rio Piquiri para jusante, até as áreas alagadas laterais entre os rios Paraguai Mirim e Negrinho. Está completando o seu ciclo de vida no Pantanal com populações adultas desovantes. A reprodução ocorre no período de águas baixas. Na região em estudo, alimentou-se de peixes de ambientes lênticos das famílias Characidae, Cichlidae e Loricariidae. Até fins de 2004, sua ocorrência estava restrita à margem esquerda do rio Paraguai, mas, nos primeiros dias de Março de 2005, alguns indivíduos foram pescados na margem direita, o que coloca uma questão a ser respondida nos próximos anos: qual será efetivamente a sua distribuição no Pantanal? A hipótese inicial de que as águas turvas do rio Paraguai constituiriam barreiras a sua dispersão não foi confirmada. Já existem registros de ocorrência na Baía Tuiuiú, Parque Nacional do Pantanal e no Pantanal boliviano, todos eles localizados na margem direita do rio Paraguai. O tucunaré possui características biológicas como desova parcelada e cuidados com a prole, entre outras, que lhe está possibilitando estabelecer-se com sucesso no Pantanal, a exemplo do que já foi observado em outros ambientes onde foi introduzido.

Palavras-chave: invasão, dispersão, reprodução, alimentação.

\section{Introduction}

The tucunaré, Cichla piquiti, is a native fish species from the Amazonian watershed that was introduced into the Pantanal probably in 1982, as a consequence of escaping from culture fish ponds in the Upper Piquiri River. Its original area of occurrence is the Araguaia and Tocantins River drainages (Kullander and Ferreira, 2006). Its distribution from 1992 to 1994 was restricted to the Piquiri river watershed (Nascimento et al., 2001). The introduction of Cichla ocellaris into Lake Gatun, Panamá, caused severe reduction of native fish species 
diversity (Zaret and Payne, 1973; Zaret, 1974). The introduction of the same species into the coast channels of the southeastern region of Florida didn't have the same consequences as in Lake Gatun and had socio-economic benefits for the local human population (Shafland, 1995, 1996, 1999a). According to Shafland (1996, 1999b), no other region in the world has had so many cases of the introduction of exotic fishes as in Florida. The potential deleterious effects of these introductions have been a major concern of local authorities for a long time. This concern is now unwarranted, since it hasn't caused any native fish species extinction or environmental or economic catastrophes, at least in the Florida region. In Brazil, decrease in richness and diversity of native fish fauna has been observed in the State Park of Doce River as a consequence of introduction of exotic fish species, included Cichla cf. monoculus (Latini and Petrere-Jr, 2004); the authors tried to explain the negative impacts of these introductions through the behavior relationships among the native and exotic species, such as parental care and predation.

Zaret (1980) discussed the success of Cichla ocellaris introduction in Central America, based on its biological characteristics and the fact that it originates from lentic environments. Several aspects enable cichlids to be successful in the exploration and use of lentic environments, such as their fins and associated musculature ideally suited for accurate and fine controlled movements, including the ability to fan water, which makes them capable to rear young in oxygen-depleted lakes by providing a steady flow of water over the developing eggs, and the well-developed oral incubation of young or nesting, providing protection against predation in this critical phase of development. According to Moyle and Marchetti (2006), there are a number of characteristics, both of the invader and of the place to be invaded, that increases the probability of an invader being successful, such as if it has a history of successful establishment outside its native range, if it has characteristics likely to promote success at multiple stages of the invasion process, introduction into a habitat that more or less matches its native habitats, comparatively high fish species richness and if it is introduced repeatedly with propagule sizes exceeding 100 individuals.

This study is a continuation of that carried out by Nascimento et al. (2001), an attempt to monitor the dispersion of the tucunaré in the Pantanal over the years since its introduction and, at the same time, to get information on its biology and ecology.

\section{Material and Methods}

For determining the tucunaré occurrence area in the Pantanal, questionnaires with a photo of Cichla piquiti (easily identifiable, if a photo is available) were sent to "piloteiros", who are the professionals that help sports fishermen in their activities. Using their responses, it was possible to map the occurrence area of the tucunaré and to choose the places to sample them for biological studies (Marques and Resende, 2005a). Captures were made in the region named "Chané", near "Baía Vermelha" (where tucunarés are very abundant), located $204 \mathrm{~km}$ upstream of Corumbá city, in October, 2003 and February, 2005. The fishes were sampled using gillnets of different mesh sizes and by the use of rod with artificial baits. Data such as total length, standard length, total weight, sex, and stage of gonad development were taken for each fish and stomachs were extracted to study feeding habits. Piloteiros and sport fishermen also helped by collecting stomachs with food in the Chané region and sending them to us for analysis together with capture place and size. The stomachs were fixed in formalin $10 \%$ for further analysis of content in the laboratory. Temperature of water $\left({ }^{\circ} \mathrm{C}\right)$, oxygen content $\left(\mathrm{mg} \cdot \mathrm{L}^{-1}\right), \mathrm{pH}$, conductivity $(\mu \mathrm{S} / \mathrm{s})$ and transparency of water, using the Secchi disc were taken, all of them in the Chané region, except for the Negrinho River, a tributary of the Paraguay Mirim River, where only transparency of water was taken.

The population structure of the tucunare was studied by frequency distribution of total length classes. The estimation of the reproduction period was done through the frequency analyses of gonad maturation stages. The gonadal maturation stages used were: I - immature: II- in maturation; III - mature; IV- spent and V - resting.

The food items found in the stomachs were identified as much as possible, using the Manual of Fish identification of the Pantanal (Britski et al., 1999). The feeding diet was determined using the methodology developed by Kawakami and Vazzoler (1978), as follows:

$\mathrm{IAi}=\left[(\mathrm{Fi} * \mathrm{Vi}) / \sum_{\mathrm{i}=1}^{\mathrm{n}}(\mathrm{Fi} * \mathrm{Vi})\right] * 100$

where IAi $=$ alimentary index; $i=1,2, \ldots \mathrm{n}$ food item: $\mathrm{Fi}=$ occurrence frequency percentage and $\mathrm{Vi}=$ volumetric frequency percentage.

\section{Results}

The tucunare introduced into the Pantanal was identified as Cichla piquiti, originally from the TocantinsAraguaia river Basin, based on Kullander and Ferreira's (2006) review of South American cichlid genus Cichla. The occurrence area of "tucunaré" is shown in Figure 1. It is found in the clear waters along the left bank of Piquiri and Paraguay Rivers south until Paraguay Mirim and Negrinho Rivers. Few specimens were captured along the right bank of Paraguay River after year 2005. Figure 2 shows one specimen found in Lake Tuiuiú, on the right bank of the river Paraguay. Specimens of this species are in the Reference Fish Collection of the Pantanal at Embrapa-Pantanal (www.cpap.embrapa.br) located in Corumbá, Mato Grosso do Sul State, Brazil.

Physical and chemical properties of the water from the environment of occurrence of the tucunaré are shown in Table 1. The common characteristic in all the environ- 


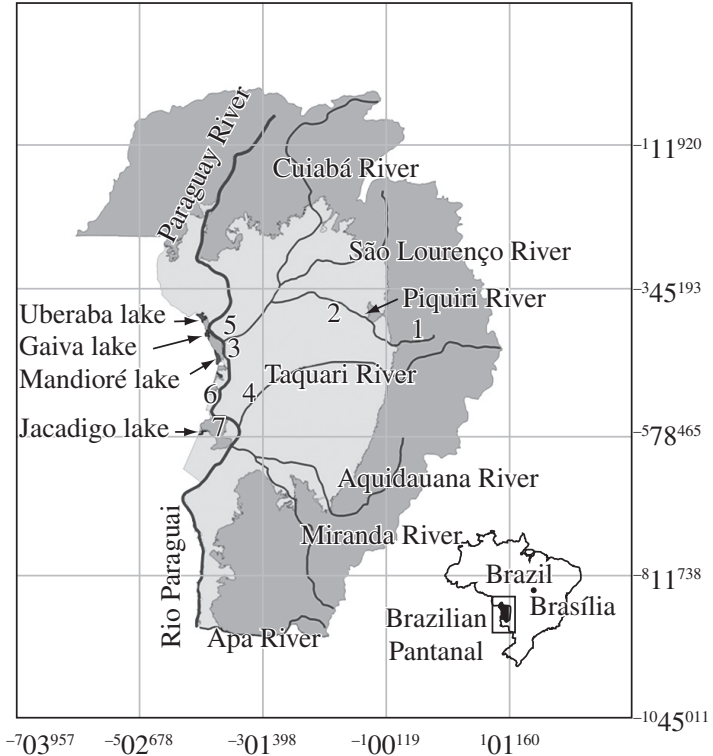

Figure 1. Upper Paraguay River Basin (dark green), which contains Pantanal (light green). 1) Upper Piquiri River; 2) lateral flooded area of Piquiri River; 3) Chané region (extensive lateral flooded area of Paraguay River); 4) Negrinho River (extensive flooded area connected to Paraguay-Mirim River, a lateral left arm of the Paraguay River); 5) Pantanal National Park; 6) Tuiuiú Lake ; and 7) Corumbá city.

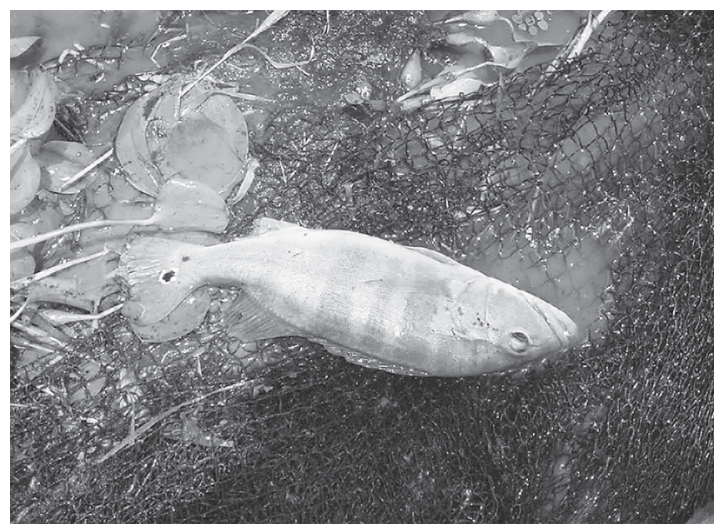

Figure 2. Tucunaré, Cichla piquiti, found in the Lake Tuiuiú, on the right bank of the Paraguai River, near Corumbá city, South Pantanal.

ments where tucunaré were found was the clearness of the water with transparency ranging from 126 to $193 \mathrm{~cm}$. Conductivity was low, varying from 27.4 to $63 \mu \mathrm{S}, \mathrm{pH}$ from 6.03 to 6.19 and oxygen content, from 0.69 to 4.07 mg. $\mathrm{L}^{-1}$.

The total length of the tucunaré ranged from 26 to $50 \mathrm{~cm}$, with predominance of fishes from 32 to $44 \mathrm{~cm}$ (Figure 3), showing a well structured population, as can be seen in the topic on reproduction.

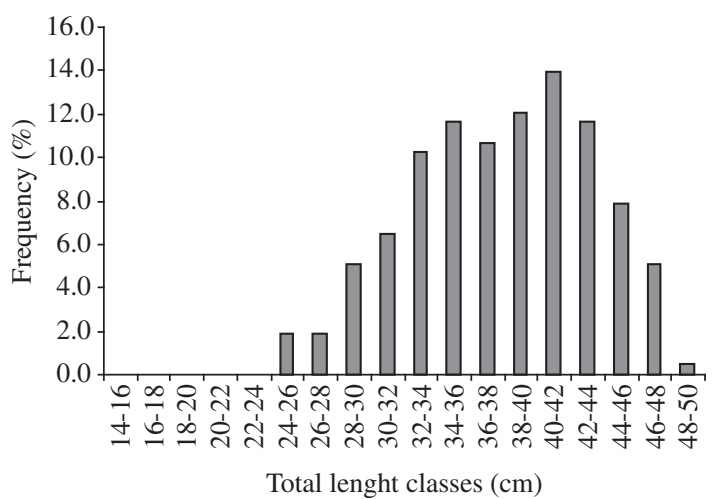

Figure 3. Frequency distribution of total length classes of Cichla piquiti in the Pantanal.

Fishes were the main food of the tucunaré (Table 2). The results from 2004 were from fishes captured by sports fishermen in the Chané region, whose size varied from 28 to $50 \mathrm{~cm}$, with one of $15 \mathrm{~cm}$ and another of $52 \mathrm{~cm}$. Occasionally, plant debris (fruits, monocotyledon and dycotiledon pieces, non-identified debris), insects (chironomid and non-identified remains) and sediment were found. Due to the advanced stage of digestion, the majority of fishes eaten by the tucunaré could not be identified. Fish items that could be identified were Serrasalmus spilopleura, Apareiodon affinis, Chaetobranchopsis australis and Leporinus lacustris, as well as fishes belonging to the families Characidae, Cichlidae, and Loricariidae, all typical from lentic environments. Unidentified fish eggs were found in the stomach of some tucunaré.

Figures 4 and 5 present the relative frequency distribution of gonad maturation stages of males and females of the tucunaré, in October 2003 and February 2005. Fish with immature gonads were not found. In October 2003, males and females had gonads in development stages II and III, which represent maturation and mature stages respectively, indicating that spawning is almost ready to happen. In February 2005, almost all the males and females were in stage IV, spent, meaning the ending of spawning. So, reproduction of the tucunare in the Pantanal occurs during low waters, as in the Amazon.

Males attain larger sizes and with more frequency than females (Figure 6). The most frequent length classes for females were between 27 and $36 \mathrm{~cm}$, while for males it was between 36 and $42 \mathrm{~cm}$. The sampled population had $40.6 \%$ of females and $59.4 \%$ of males.

\section{Discussion}

According to Kullander and Ferreira (2006) the tucunaré introduced into the Pantanal is Cichla piquiti, inhabiting Araguaia-Tocantins drainage. The main characteristic of the Cichla piquiti is the pattern of long bars from the dorsal to ventral region and its typical blue 
Table 1. Localization and physico-chemical water characteristics of the freshwater environments of occurrence of Cichla piquiti in the Pantanal.

\begin{tabular}{|c|c|c|c|c|c|c|c|c|}
\hline Site & $\begin{array}{c}\text { Latitude } \\
\text { (S) }\end{array}$ & $\begin{array}{c}\text { Longitude } \\
\text { (W) }\end{array}$ & Date & $\begin{array}{c}\text { Temp } \\
\left({ }^{\circ} \mathrm{C}\right) \\
\end{array}$ & $\mathbf{p H}$ & $\begin{array}{c}\text { Conductivity } \\
(\mu \mathrm{S} / \mathrm{s})\end{array}$ & $\begin{array}{r}\text { Oxygen } \\
\left(\mathrm{mg.L} \mathbf{L}^{-1}\right) \\
\end{array}$ & $\begin{array}{c}\text { Transparency } \\
(\mathbf{c m})\end{array}$ \\
\hline C. Piúva & $18^{\circ} 09^{\prime} 59.3 "$ & $57^{\circ} 19^{\prime} 49.4^{\prime \prime}$ & $17 / 07 / 2003$ & 21.0 & 6.05 & 27.4 & 2.05 & 167 \\
\hline C. São José & $18^{\circ} 10^{\prime} 17.3^{\prime \prime}$ & $57^{\circ} 21^{\prime} 24.5^{\prime \prime}$ & $18 / 07 / 2003$ & 21.0 & 6.30 & 30.0 & 1.45 & 193 \\
\hline C. São José & $18^{\circ} 10^{\prime} 35.3^{\prime \prime}$ & $57^{\circ} 20^{\prime} 36.9^{\prime \prime}$ & $01 / 10 / 2003$ & 26.1 & 6.05 & 50.0 & 0.69 & 157 \\
\hline C. Piúva & $18^{\circ} 10^{\prime} 23.6^{\prime \prime}$ & $57^{\circ} 19^{\prime} 11.2^{\prime \prime}$ & 01/10/2003 & 27.3 & 6.69 & 63.0 & 4.07 & 126 \\
\hline B. S. Pedro & $18^{\circ} 10^{\prime} 34.0^{\prime \prime}$ & 57" 22'38.1" & $14 / 02 / 2005$ & 32.0 & 6.03 & 35.1 & 3.53 & 160 \\
\hline C. Piúva & $18^{\circ} 10^{\prime} 02.1$ " & $57^{\circ} 19^{\prime} 36.0^{\prime \prime}$ & $16 / 02 / 2005$ & 32.0 & 6.19 & 35.7 & 3.32 & 168 \\
\hline Rio Negrinho* & $18^{\circ} 49^{\prime} 18.1^{\prime \prime}$ & $57^{\circ} 19^{\prime} 56.1^{\prime \prime}$ & $10 / 03 / 2003$ & No data & No data & No data & No data & To the bottom \\
\hline
\end{tabular}

Table 2. Alimentary indices for Cichla piquiti, by period of sampling, in the region of Chané (São Pedro Lake, "Corixo" Piúva,...) in the Paraguay river, Pantanal.

\begin{tabular}{lccc}
\hline Food item & $\begin{array}{c}\text { October/03 } \\
(\mathbf{N}=\mathbf{6})\end{array}$ & $\begin{array}{c}\text { Year 04 } \\
(\mathbf{N}=\mathbf{6 4})\end{array}$ & $\begin{array}{c}\text { February/05 } \\
(\mathbf{N}=\mathbf{1 7})\end{array}$ \\
\hline Fishes & 99.2 & 95.8 & 100.0 \\
Insects & 0.3 & 0.1 & 0.0 \\
Plant debris & 0.5 & 2.4 & 0.0 \\
Sediment & 0.0 & 1.7 & 0.0 \\
\hline
\end{tabular}

$\mathrm{N}=$ number of stomachs with food content.

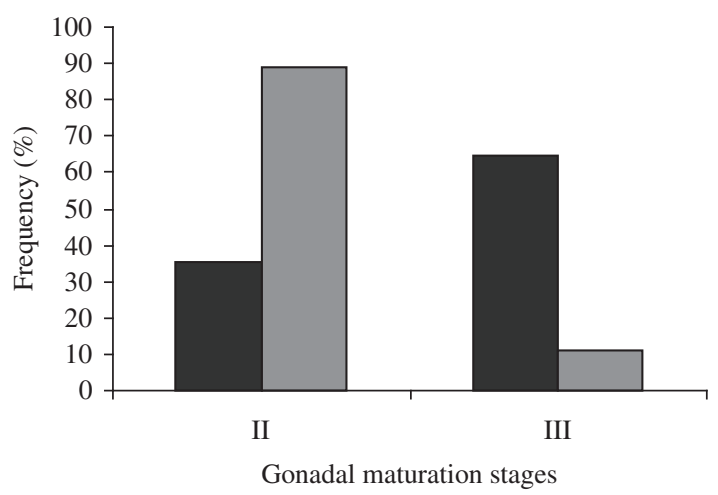

Figure 4. Frequency distribution of gonadal maturation stages of males (black) and females (grey) of Cichla piquiti in the Pantanal, October, 2003.

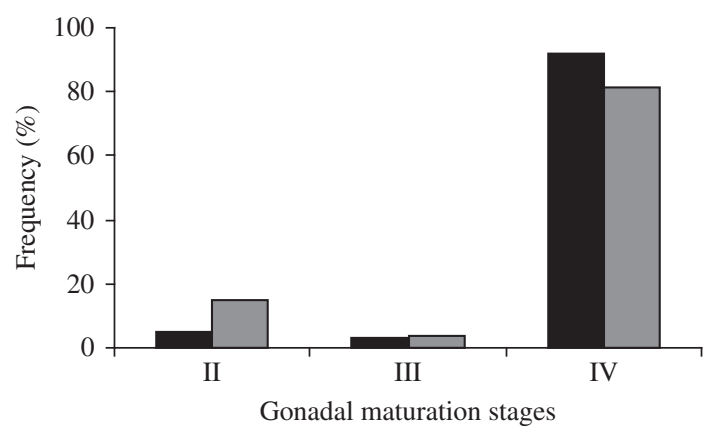

Figure 5. Frequency distribution of gonadal maturation stages of males (black) and females (gray) of Cichla piquiti in the Pantanal, February, 2005.

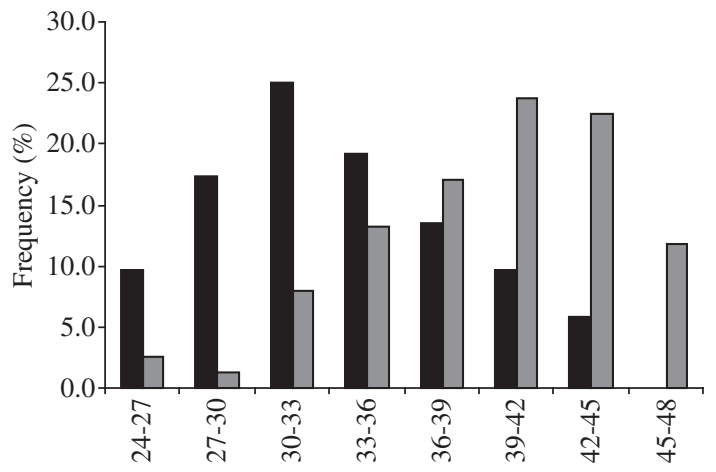

Total lenght classes $(\mathrm{cm})$

Female $\square$ Male

Figure 6. Total length classes frequency distribution of Cichla piquiti females and males in the Pantanal.

color in the belly, when they are in very clear waters. The tucunaré was seen for the first time in the Pantanal in the Piquiri River in 1982. Its introduction to the Pantanal was a consequence of rupture of fish culture ponds in the highlands of the Piquiri River. In November 1992 and January 1994, the tucunaré was found only in the Piquiri River (Nascimento et al., 2001). In recent years, fishermen have caught tucunaré downstream along the clear water bodies on the left bank of the Paraguay River. In 2000 it was found in the Negrinho River, in a floodable area connected to the Paraguay-Mirim River, which is an arm of the Paraguay River, near Corumbá city. In 2000, it was also registered in the Chané region, an extensive clear water area on the left bank of the Paraguay River. The big flood of 1995 may have been responsible for the dispersion of the tucunaré, since large areas of clear waters occur during rising waters, connecting all the water bodies along the left bank of the Paraguay River. In 2004, large amounts of tucunaré were caught by fishermen in the "corixos" of Mata-Cachorro, Piúva and São José, in the Chané region. "Corixo" means a small river originating from overflowing waters of the main river during the flooding season; its permanency throughout the year 
depends on the yearly flooding (Marques and Resende, 2005 b). In the beginning of 2005, some tucunaré were captured in the port of Corumbá, as in other regions such as the Tuiuiú Lake, an oxbow lake of the Paraguay river near Corumbá, in October 2005 and February 2006 (Resende, personal observation), as well in the National Park of the Pantanal (Lima, 2006, pers. com.) and in the Bolivian Pantanal (Jegu, 2006, pers. com.), all of them on the right bank of the Paraguay river.

Studies carried out by Nascimento et al. (2001) supposed that turbid waters function as natural barriers for dispersion of the tucunare in the Pantanal, possibly because they are visually oriented predators. Thus, initial expectations were that it would remain along the left bank of the Paraguay River, but the finding of tucunaré on the right bank of the Paraguay River in 2005 indicates that, in the future, it will spread through the entire Pantanal region. Suárez et al. (2001), studying the tucunaré in the Piquiri River, found that it fed mainly on fishes, with some amount of shrimps and plant debris. They identified 21 fish species in the diet where Curimatella dorsalis was the main food in number. None of the fish species found by Suarez (op. cit) was identified in this study. Unidentified fish eggs have been found in the stomach of some tucunaré, possibly as a result of their own species nest predation or from other species that spawned at that time. The results of this study, together with those of Nascimento et al (2001), indicate that tucunare is a generalist fish eater, preying on whatever it can swallow. Underwater observations done by Resende in the Chané region, in October 2005, showed C. piquiti swimming together with other fish species, like Prochilodus lineatus, Serrasalmus spp., Pygocentrus nattereri, and Myleinae subfamily species in an apparently friendly way. It seems that some degree of coexistence can be found, even being a predator, due to the large sized body of these species that cannot be swallowed, as pointed out by Suárez et al. (2001). The same is not true for small species and for species of slender bodies.

It is known that cichlids of genus Cichla belong to the reproductive type "guarder" or "substrate spawners" (Zaret, 1980). Cichla can lay eggs on a substrate and both parents remain guarding the offspring for up to several months. In some cases it is possible to see young swimming in shoals with one of the parents (Resende, pers. obs.). It is recognized also as multi-spawners (Chellapa et al., 2003; Gomiero and Braga, 2004a) due to the simultaneous occurrence of oocytes of different sizes in the ovaries. These reproductive strategies can explain the success of its introduction on new environments, as in the Pantanal. Adult population with mature and spent gonads found in the Pantanal clearly indicates a well-established population that renews their stock every year. No immature fish was captured, possibly due to the sampling gear used in this study.

The gonad maturation stages data from 2003 and 2005 could be used for determining the spawning season, as these years had similar water level fluctuation, the fundamental factor that triggers reproduction in rivers with a large floodplain, as with the Paraguay River (Welcomme, 1985; Resende et al., 1996). The spawning season of $C$. piquiti occurs when the water level is low in the Paraguay River studied area, from October to February. Reproduction throughout dry to flooding seasons seems a characteristic of Cichla species (Winemmiler et al.,1997; Jepsen et al.,1999; Gomiero and Braga, 2004a). According to Zaret (1980) and Chellapa et al. (2003), the onset of sexual maturity in males of Cichla was marked by the appearance of a bright yellowish-orange post-occipital cephalic protuberance, approximately 2 weeks prior to spawning, not found in immature males. Males of $C$. piquiti with these protuberances were observed in the Pantanal during the months of October 2003 and February 2005, revealing the same behavior as in the Brazilian northeastern region. Possibly, the energy stored as lipid in this protuberance gives the males enough energy to guard the nests and young during the reproductive season; they are absent in spent males. A similar characteristic can be seen in a native cichlid Gymnogeophagus balzani of the Pantanal (Resende, pers. ob.). Males larger than females seem to be related to their reproductive strategy, as large males are more successful in protecting the eggs and young, as observed by Zaret (1980) and Perrone (1975, in Zaret, 1980).

The results of this work reveal that $C$. piquiti is well established in the Pantanal. No visible deleterious effect on native fish species has been observed, as in Central America (Zaret, 1974) and the Paraná River (Santos et al., 1994 apud Agostinho et al., 2007), at least in the Chané region. The evidence up to now suggests that, in the long term, co-existence among Cichla piquiti and native fishes will be reached in the Pantanal as observed in Florida for Cichla ocellaris. Local fishermen continue to fish the same species as in the past and now they say it is better, as tucunare is good for fishing and for consumption. The tucunaré have now crossed the Paraguay River and can also be found on the right bank, meaning that in the future, it will be dispersed through the entire Pantanal region.

The impact of introduction seems to depend on the richness and diversity of native fish assemblages. As cited by Gomiero and Braga (2004b) "tucunarés do not cause overbalance in their natural environments owing to the adaptation of countless species of prey to predatory pressure and to the great number of competing piscivorous species", a situation that seems to be occurring in the Pantanal, as more than 260 fish species are found and diversity is high (Resende and Palmeira, 1999; Resende and Machado, 2002; Marques and Resende, 2005b). However, the well succeeded introduction of tucunaré in the Pantanal cannot be used as an argument for more introductions. The tucunaré is very appreciated for sports fishing and takes part in fish landing statistics in the Pantanal (Albuquerque et al., 2005), as has been occurring in Florida (Shafland, 1993; 1996; 1999a; 1999b). If 
desire to control the tucunaré population exists, a specific fishing program for it can be developed.

According to Moyle and Marchetti (2006) a set of characteristics of fishes belonging to the genus Cichla, such as a history of success of invasion in several environments (Zaret,1974; Shafland, 1995; 1999a; 1999b; Latini and Petrere-Jr, 2004), parental care, medium to long life span, moderate size and being piscivorous, can explain the success of invasion of the fishes belonging to this genus as is occurring in the Pantanal.

The phenomenon of exotic fish species establishing themselves in new environments without damage to local native fish species seems to be related to local diversity (Latini and Petrere-Jr, 2004). Further studies will be needed to monitor the distribution of the tucunare in the future as well as to evaluate its impact on native fish, if this exists. The expectation is that the tucunaré will be established in the entire Pantanal region in the next years, the time it took to invade and to establish itself on the left bank of the Paraguay River and across to right bank.

Acknowledgements - We are grateful for the financial support from Fundect, the State Foundation for Education, Science and Technology in Mato Grosso do Sul.

\section{References}

AGOSTINHO, AA., GOMES, LC. and PELICICE, FM., 2007. Ecologia e Manejo de Recursos Pesqueiros em Reservatórios do Brasil. Maringá: Eduem. p. 339-372.

ALBUQUERQUE, SP., CAMPOS, FLR. and CATELLA, AC., 2005. Sistema de Controle de Pesca de Mato Grosso do Sul SCPESCA/MS 9 -2002. Corumbá: Embrapa Pantanal; Campo Grande: SEMA-IMAP. (Boletim de Pesquisa e Desenvolvimento/Embrapa Pantanal, 47). 57 p.

BRITSKI, HA., SILIMON, KZS. and LOPES, BS., 1999. Peixes do Pantanal. Manual de identificação. Brasília: Embrapa-SPI, Corumbá: Embrapa-CPAP. 184 p.

CHELLAPPA, S., CAMARAM, M. and CHELLAPA, N., 2003. Ecology of Cichla monoculus (Osteichthyes: Cichlidae) from a reservoir in the semi-arid region of Brazil. Hydrobiol., vol. 504, no. $1-3$, p. 267-273.

GOMIERO, LM., BRAGA, FMS., 2004a. Reproduction of species of the genus Cichla in a reservoir in Southeastern Brazil. Braz. J. Biol. = Rev. Bras. Biol., vol. 64, no. 3b, p. 613-624.

-, 2004b. Feeding of introduced species of Cichla (Perciformes, Cichlidae) in Volta Grande reservoir, River Grande (MG/SP). Braz. J. Biol. = Rev. Bras. Biol., vol. 64, no. 4, p. 787-795.

JEPSEN, DB., WINEMILLER, KO., TAPHORN, DC., OLARTE, DR., 1999. Age structure and growth of peacock cichlids from rivers and reservoirs of Venezuela. J. fish Biol., vol. 55 , no. 2 , p. $433-450$.

LATINI, AO. and PETRERE Jr, M., 2004. Reduction of a native fish fauna by alien species: an example from Brazilian freshwater tropical lakes. Fish. Manag. and Ecol., vol. 11, no. 2, p. $71-79$.
KAWAKAMI, E. and VAZZOLER, G., 1980. Método gráfico e estimativa do índice alimentar aplicado no estudo de alimentação de peixes. Bol. inst. Oceanogr., vol. 29, no. 2, p. 205-207.

KULLANDER, SO., FERREIRA, EJG., 2006. A review of the South American cichlid genus Cichla, with description of nine new species (Teleostei: Cichlidae). Ichthyol. Explor. Freshwaters, vol. 17, no. 4, p. 289-398.

MARQUES, DC. and RESENDE, EK., 2005a. Distribuição do tucunaré Cichla cf monoculus (Osteichthyes, Cichlidae) no Pantanal. Corumbá: Embrapa Pantanal. 24 p. (Boletim de Pesquisa e Desenvolvimento, 60).

-, 2005b. Comunidades de peixes da RPPN SESC Pantanal. Corumbá: Embrapa Pantanal. 25 p. (Boletim de Pesquisa e Desenvolvimento/Embrapa Pantanal, 65).

MOYLE, PB. and MARCHETTI, MP., 2006. Predicting invasion success: freshwater fishes in California as a model. BioScience, vol. 56, no. 6, p. 515-524.

NASCIMENTO, FL., CATElla, AC. and MORAES, AS., 2001. Distribuição espacial do tucunaré, Cichla sp. (Pisces, Cichlidae), peixe amazônico introduzido no Pantanal, Brasil. Corumbá: Embrapa Pantanal. 15 p. (Boletim de Pesquisa, 24).

RESENDE, EK., CATELLA, AC., NASCIMENTO, FL., PALMEIRA, SS., PEREIRA, RAC. and LIMA, MS., 1996. Biologia do curimbatá,(Prochilodus lineatus), pintado (Pseudoplatystoma corruscans) e cachara (Pseudoplatystoma fasciatum) na bacia hidrográfica do rio Miranda, Pantanal do Mato Grosso do Sul, Brasil. Corumbá, MS: EMBRAPA-CPAP. 75 p. (Boletim de Pesquisa, 02).

RESENDE, EK. and PALMEIRA, SS., 1999. Estrutura e dinâmica das comunidades de peixes da planície inundável do rio Miranda, Pantanal de Mato Grosso do Sul. In 2 Simpósio sobre Recursos Naturais e sócio econômicos do Pantanal, 1996. Corumbá: Embrapa Pantanal. p. 249-282.

RESENDE, EK. and MACHADO, FA., 2002. Avaliação ecológica rápida no Parque Nacional do Pantanal e RPPNs do entorno. Componente Ictiofauna. Corumbá: Embrapa Pantanal. 56 p. (Relatório técnico).

SHAFLAND, PL., 1993. An overview of Florida's introduced butterfly peacock bass (Cichla ocellaris) sportfishery. Natura, no. 96 , p. 26-29.

-, 1995. Introduction and establishment of a successful butterfly peacock fishery in Southeast Florida canals. In International Symposium and Workshop on Uses and effects of cultured fishes in aquatic ecosystems. Schramm, Hl and Piper, RG. (Eds). Amer. Fish. Soc. Symp.

-, 1996. Exotic fish assessments: an alternative view. Rev. Fish. Sci., vol. 4, no. 2, p. 123-132.

-, 1999a. The introduced butterfly peacock (Cichla ocellaris) in Florida. II. Food and Reproductive Biology. Rev. Fish. Sci., vol. 7 , no. 2 , p. $95-113$.

-, 1999b. The introduced buttefly peacock (Ciclha ocellaris) in Florida. I. Fish community analyses. Rev. Fish. Sci., vol. 7, no. 2, p. 71-94.

SÚAREZ, IR., NASCIMENTO, FL. and CATELLA, AC., 2001. Alimentação do tucunaré, Cichla sp. (Pisces, Cichidae) - um peixe introduzido no Pantanal, Brasil. Corumbá: Embrapa Pantanal. 21 p. (Boletim de Pesquisa, 23). 
ZARET, TM., 1974. The ecology of introductions - a case study from a Central American Lake. Environ. Cons., vol. 1, no. 4, p. 308-309.

-, 1980. Life history and growth relationships of Cichla ocellaris, a predatory south American cichlid. Biotropica, vol. 12, no. 2, p. $144-157$.

ZARET, TM. and PAINE, RT., 1973. Species introduction in a tropical lake: a newly introduced piscivore can produce population changes in a wide range o trophic levels. Science, vol. 182 , no. 4111 , p. 449-455.

WELCOMME, RL., 1979. The fisheries ecology of floodplain fisheries. London: Longman. 317 p.

WINEMILLER, KO., TAPHORN, DC., BARBARINODUQUE, A., 1997. Ecology of Cichla (Cichlidae) in two blackwater rivers of Southern Venezuela. Copeia, no. 4., p. $690-696$. 